\title{
Studying the heavy metals concentration in discharged water from the Trepça Mine and flotation, Kosovo
}

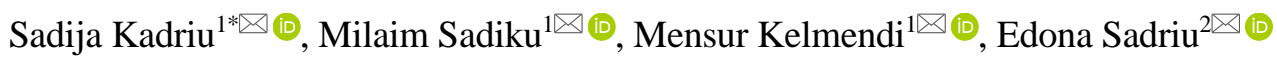 \\ ${ }^{1}$ University of Mitrovica "Isa Boletini", Mitrovicë, 40000, Kosovo \\ ${ }^{2}$ HPC International SAS, Prishtinë, 10000, Kosovo \\ *Corresponding author: e-mail sadija.kadriu@umib.net, tel. +38344736510
}

\begin{abstract}
Purpose. The purpose of this study is to assess the concentration of heavy metals in industrial discharge water from the Trepça Mine in Stantërg and flotation, and their impact in polluting the urban environment.

Methods. During the research work we have marked the sampling location. The sampling method, the amount of the sample, the transportation method and maximum time the sample can stay before the chemical analysis were all in compliance with the ISO 5667:1, 3 method. The conservation of samples for defining certain parameters was done in compliance with the American Public Health Association conservation procedure, and for the mineralization of heavy metals from the polluted discharged water samples the EPA-3015A method was applied. For defining the heavy metals concentration, the ICP - OES measuring technique was applied (the Inductively Coupled Plasma Method - Optical Emission Spectrometry).

Findings. Based on the industrial activity of Trepça Mine, it has been concluded that the main cause of environment pollution has continuously been the mine and flotation. The analysis of discharged water samples, both from the mine and the flotation depict the real situation of the heavy metals' concentration in the surrounding environment.

Originality. All laboratory analyses have been conducted with special care through the use of necessary advanced technology lab equipment, so that the obtained results would provide maximum accuracy.

Practical implications. The water samples were taken in January and June 2020, namely in winter and summer. The seasonal monitoring of heavy metals in water result with significant changes in the presence of metals as a consequence of climate changes.
\end{abstract}

Keywords: mining activity, mine water, industrial discharge water, heavy metals, pollution

\section{Introduction}

The pollution of the urban environment in Mitrovica region, since the $1970-1990^{\text {th }}$ to this day has been and remains a serious and permanent concern, not only for the population of Mitrovica region but for a host of environment researches, of different scientific categories and profiles as well. This environment pollution exists due to the fact that for a long time (more than half a century), the Trepça Mine with the entire complexity of ore processing has operated in this region [1]. "Trepça" Mine is an old enterprise established by the English (Trepça Mine Limited) active since 1927, whereas the production of ore and metals commenced in 1930. The Trepça Mine in Stantërg, is located $10 \mathrm{~km}$ northeast of Mitrovica. This mine operates as a special department of the Trepça Mining-Metallurgical-Chemical Combine in Mitrovicë. The regional Ibri road connects the mine with the nearby town of Mitrovicë, whereas the enrichment plant (flotation) for obtaining the $\mathrm{Pb}-\mathrm{Zn}$ concentrate is located in Tuneli i Parë neighborhood. The raw material extracted from the mine is lead, zinc and silver sulfide ore.
If we go back to when the Trepça Combine was established, we will see that during its development, this industrial complex, besides having an important role in the process of developing the economy of Kosovo and former Yugoslavia, at the same time, it has continuously been the biggest environment polluter in Mitrovica region. The environment pollution capacity was intricately connected with the increase of exploitation and colored metal production [2].

The mine activity should ensure a healthy environment in all aspects, including all the components of the environment: settlements, drinking water, surface water, agricultural land, etc. From the mine depths the infiltrating waters are pumped out and these waters are used for the mine and $\mathrm{Pb}-\mathrm{Zn}$ enrichment plant (flotation) needs. Due to the mine operations, the surface water flows usually have a low $\mathrm{pH}$ and contain high levels of heavy metals [3].

It is known that from the $1970^{\text {th }}$ and through the $1990^{\text {th }}$, the Trepça Combine was the greatest producer in Europe of $\mathrm{Pb}, \mathrm{Zn}, \mathrm{Cd}, \mathrm{Bi}, \mathrm{Ag}$, etc. Therefore, the distortion of the ecological borderline, between the industrial zone and the urban 
environment occurred as a consequence of this rapid industrial development. Despite the lack of rocks remaining in Stantërg Mine the mine waters continue to be pumped from the I level to Tuneli i Parë. River Trepça runs nearby and it collects the waters of various natural sources from villages Mazhiq, Vidishiq and Rashan.

These initially clean waters, upon arriving near the mine get mixed with the turbid waters polluted with heavy metals that come out of the mine that pollute not only Trepça River, but also impact the environment pollution down its stream. The mine waters may contain considerably amounts of dissolved ions of heavy metals, thus, besides the pollution also cause considerable loss of precious metals [4]-[6].

As in the past, also today, examinations continue to be conducted pertaining to the causes and consequences caused by the industrial discharges in the Trepça River flow.

For this reason, in 1975 the management of the Trepça Combine, created the industrial waste landfill in an area of $2-3 \mathrm{~km}$ in village Kelmend, between two hills, in northeast Mitrovica [7]. Despite this, however, the discharging of waters from the industrial activity in Trepça River, from time to time continues to this day. As such, the Kelmend landfill is still active with a depositing capacity of 8.2 million cubic meters in an area of 18.4 hectares [8]. The material (sterile) composed of $40 \%$ sterile and $60 \%$ water in the shape of a mixed solution, is transported through pipes (hydraulic transportation) from the flotation to the landfill.

In Figure 1, the topographic map shows the mine location, the ore enrichment plant, Trepça River, industrial waste (sterile) deposit, including the sampling points marked as: $\mathrm{M}_{1}, \mathrm{M}_{2}, \mathrm{M}_{3}$ and $\mathrm{M}_{4}$.

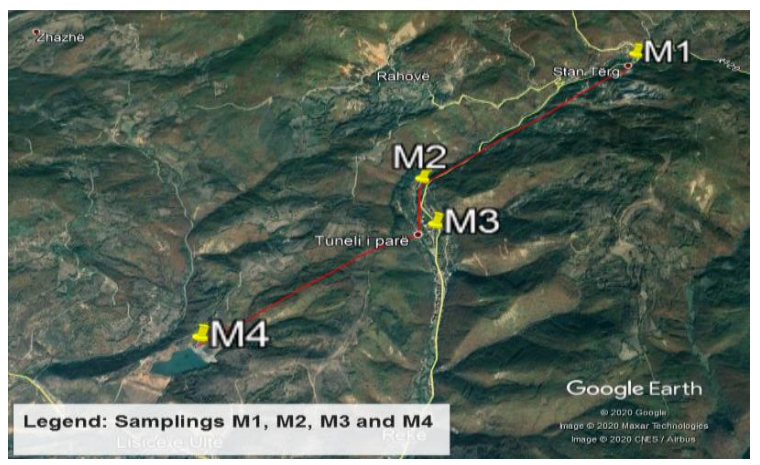

Figure 1. Topographic map

With the aim of protecting the Trepça River waters from the mine and flotation activities, monitoring the concentration of heavy metals in discharged waters from these two potential pollution sources became a necessity.

In the vicinity, around the mine, in an area of 10 thnd. hectares there are several drinking water sources, which have gone dry as a result of the mining activity in the depths of the mine. These drinking sources dried out, because the water penetrated through the rock cracks from the surface into the mine galleries, thus, continuously increasing the water volume inside the mine.

On many occasions the galleries were flooded by these waters despite the pumping activity. These waters, after getting in contact with the metal ore locations, after getting polluted with heavy metals, are discharged in the Trepça River flow, thus, together with the flotation waters, not only pollute the Trepça River but also pollute the surrounding environment.

\section{Industrial waters of Trepça Mine in Stantërg}

The Stantërg Mine falls in the category of deep mines, because of that the lowest open point of the mine determines the water collecting cone. Complete hydro-geological studies of both the mine and the surrounding area have been conducted.

On the other hand, limestone rocks, in all their modifications, constitute the main underground water collector in the ore containing Stantërg region. Hydro-geological studies have confirmed the connection between the amount of water flowing in the mine and the amount of precipitations in the region, and consequently it has been concluded that the natural flow of underground waters in the water collecting level varies from 3-6.2 $\mathrm{m}^{3} / \mathrm{min}$ (Fig. 2).

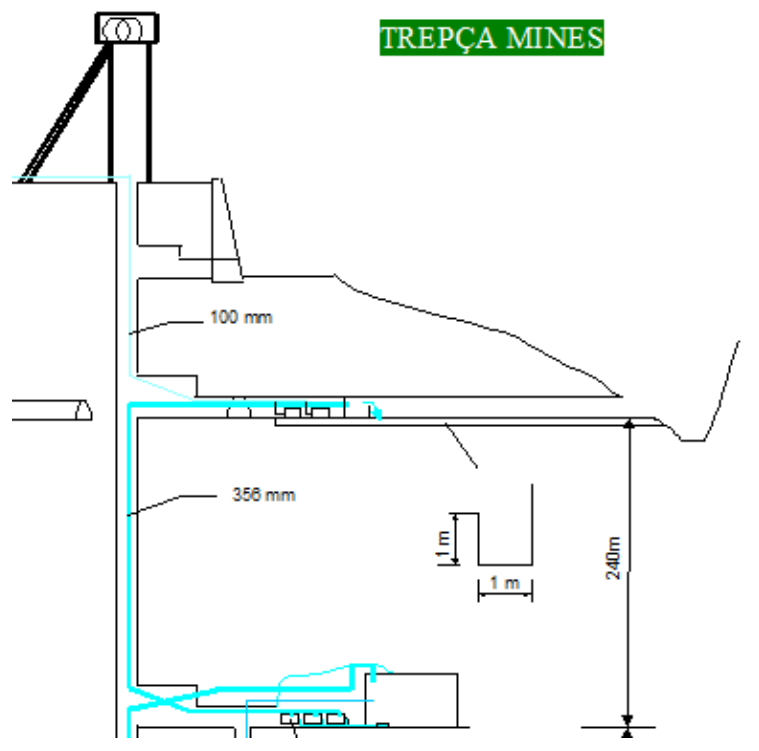

Figure 2. Sampling point $\left(M_{1}\right)$ waters removed from the mine depth

The water coming out of the Stantërg Mine, is chemically neutral or slightly basic $(\mathrm{pH}=7.0-7.2)$, physically the water carries tiny drops of rocks and mineralized environments it runs through. As shown in Figure 2, a water sample has been taken from lab treatment in order to confirm the presence or absence of heavy metals and this sample was marked $\left(\mathrm{M}_{1}\right)$. These waters are used during the ore enrichment process in the Tuneli i Parë flotation, located at a certain distance from the mine. The use of these waters, both in the enrichment process and the sterile depositing process, in the shape of a solution, is monitored to prevent polluting the river with heavy metals originating from the Trepça Mine. However, the pollution of river waters has occurred in the past and continues today as well.

\section{Monitoring the industrial discharge waters and Trepça River waters}

In the area near the Trepça Mine, runs Trepça River. The water flow from precipitations and natural springs has created Trepça River. The length of this river that runs through the terrain topography near the mine area is $12 \mathrm{~km}$. This river also runs near the ore enrichment plant (flotation), namely $2.7 \mathrm{~km}$ from the mine (Fig. 3).

Taking a water sample $\left(\mathrm{M}_{2}\right)$ from this river aims to analyze the purity of this water prior to contacting the mineralized area and prior to the contact with industrial waters discharged from the mine and the flotation. 


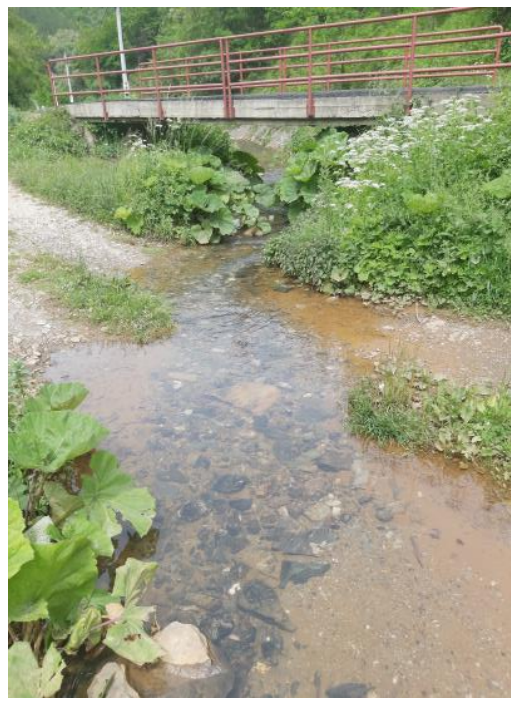

Figure 3. Sampling point $\left(\mathrm{M}_{2}\right)$ in Trepça River

The river monitoring was done in relation to climate changes during both high and low precipitation months. Considering that an amount of underground waters is used for the flotation needs during the ore enrichment process, these waters are then continuously discharged in Trepça River, thus, the river flow carries mineralized drops of various metals (Fig. 4).

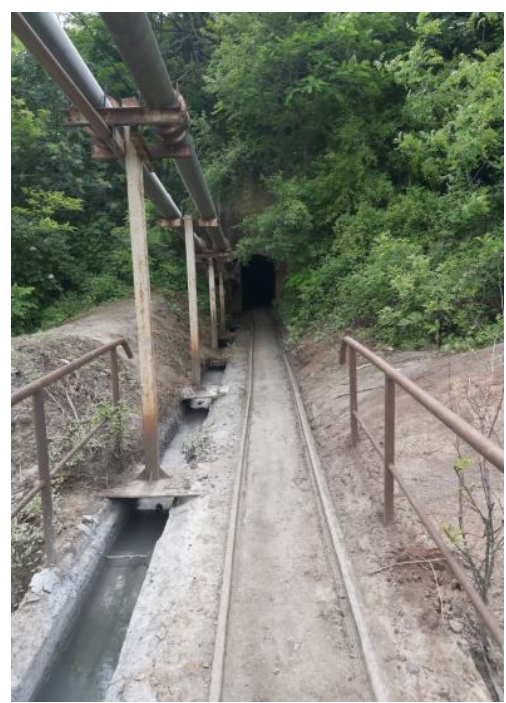

Figure 4. Discharging of industrial waters from the flotation

Due to the flotation needs for sufficient water for the ore flotation process, these waters are used until the conclusion of one flotation cycle, and after completion the water is then discharged in Trepça River (Fig. 5).

Figure 5 clearly shows the merging of industrial water, directly discharged into Trepça River, therefore, with the aim of registering the concentration of heavy metals we have marked sample point $\mathrm{M}_{3}$ along the merged flow of these waters.

Figure 6 shows the flotation industrial waste landfill in village Kelmend. For the construction of the landfill a $1676 \mathrm{~m}$ long corridor was opened from Tuneli i Parë near the enrichment plant to carry the discharge in Kelmend Field [9]. The amount of sterile, obtained as waste during the flotation, is mixed with water inside the flotation thus creating a solution in the shape of hydro pulp that is sent through pipes to the industrial waste landfill in Kelmend (Fig. 6).

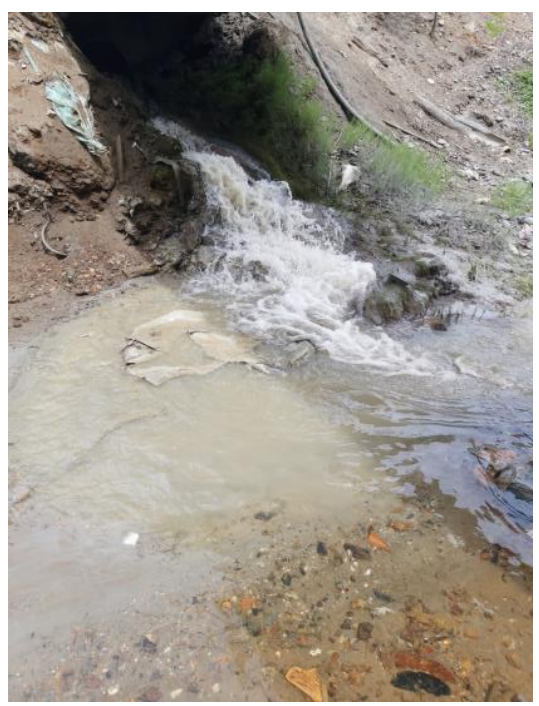

Figure 5. Sample point $\left(\mathrm{M}_{3}\right)$ discharged waters from the flotation in Trepça River

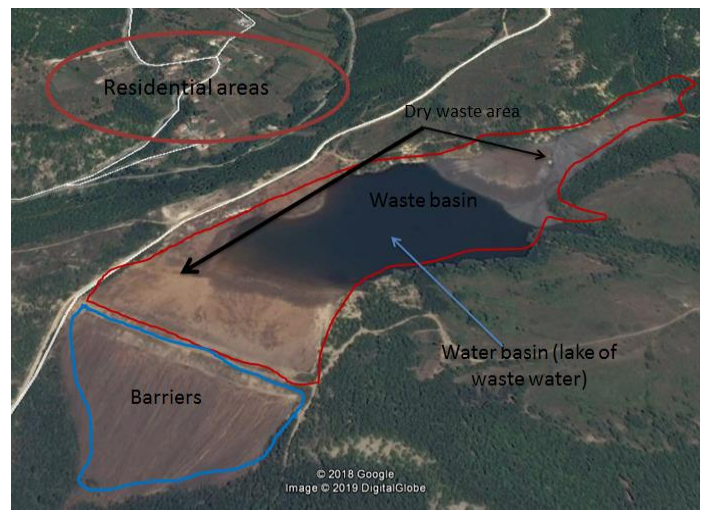

Figure 6. Sample point (M4) water flow from the Kelmend landfill

The precipitate lake is located at the center of the landfill, wherein the waste (sterile) composition varies depending on the enrichment process at the flotation. The waters flowing from the landfill and the landfill lake through the landfill drainage are marked as sample point $\mathbf{M}_{4}$.

The purpose of this study is to assess the concentration of heavy metals in industrial discharge waters from the Trepça Mine in Stantërg and flotation. The discharging of polluted, unprocessed, or insufficiently processed waters that contain considerable amounts of heavy metal ions cause major environment damages [10].

\section{Material and methods}

The sampling method, the amount of the sample, the transportation method and maximum time the sample can stay before the chemical analysis were all in compliance with the ISO [11], [12] method. The conservation of samples for defining certain parameters was done in compliance with the APHA conservation procedure [13]. The EPA-3015A method was applied in preparing the water sample for measuring-extracting (mineralization) of heavy metals [14], and for defining the heavy metals concentration the ICP - OES (the Inductively Coupled Plasma Method - Optical Emission Spectrometry) measuring technique was applied. The concentrations of the following metals in the waters have been determined: $\mathrm{Pb}, \mathrm{Zn}, \mathrm{Ni}, \mathrm{Fe}, \mathrm{Cd}, \mathrm{Cu}$, 
$\mathrm{Mn}, \mathrm{As}$ and $\mathrm{Sb}$. The experimenting part was conducted at the Agrovet private lab in Fushë Kosovë, this lab is accredited by the Kosovo Accreditation Agency.

\section{Results and discussion}

The lab results of natural and industrial water samples: $\mathrm{M}_{1}, \mathrm{M}_{2}, \mathrm{M}_{3}$ and $\mathrm{M}_{4}$ are shown in Tables 1 and 2, and graphically in Figure 7, wherein the results of each analyzed sample are argued and elaborated. The referring basic value of heavy metal concentration was taken from Administrative Instruction of MMPH-No.30/2014 of Kosovo [15]. This instruction addresses the permitted limit values of polluted water parameters, which can be discharged in public sewage system and hosting environment.

Table 1. Heavy metal concentration results according to sampling points in January 2020

\begin{tabular}{ccccccc}
\hline \multirow{2}{*}{ Parameters } & $\begin{array}{c}\mathrm{Unit} \\
\mathrm{mg} / \mathrm{l}\end{array}$ & $\begin{array}{c}\mathrm{UA} \\
30 / 2014\end{array}$ & $\mathrm{M}_{1}$ & $\mathrm{M}_{2}$ & $\mathrm{M}_{3}$ & $\mathrm{M}_{4}$ \\
\hline $\mathrm{As}$ & $\mathrm{mg} / \mathrm{l}$ & 0.1 & 0.025 & $<0.002$ & $<0.002$ & $<0.002$ \\
$\mathrm{Cd}$ & $\mathrm{mg} / \mathrm{l}$ & 0.02 & 0.006 & 0.001 & 0.009 & 0.01 \\
$\mathrm{Cu}$ & $\mathrm{mg} / \mathrm{l}$ & 0.5 & 0.012 & 0.022 & $<0.001$ & $<0.001$ \\
$\mathrm{Fe}$ & $\mathrm{mg} / \mathrm{l}$ & 2 & 0.77 & 0.52 & 0.001 & 0.001 \\
$\mathrm{Mn}$ & $\mathrm{mg} / \mathrm{l}$ & 2 & 0.670 & 0.430 & 3.590 & 0.545 \\
$\mathrm{Ni}$ & $\mathrm{mg} / \mathrm{l}$ & 0.5 & $<0.0005$ & $<0.0005$ & 0.006 & $<0.0005$ \\
$\mathrm{~Pb}$ & $\mathrm{mg} / \mathrm{l}$ & 0.5 & 0.27 & 0.48 & $<0.001$ & 0.0041 \\
$\mathrm{Sb}$ & $\mathrm{mg} / \mathrm{l}$ & 0.75 & $<0.002$ & 0.001 & 0.006 & $<0.002$ \\
$\mathrm{Zn}$ & $\mathrm{mg} / \mathrm{l}$ & 1 & 0.02 & 1.11 & 3.330 & 0.19 \\
$\mathrm{pH}$ & - & $6.5-9.0$ & 7.93 & 7.10 & 8.03 & 7.6 \\
\hline
\end{tabular}

Table 2. Heavy metal concentration results according to sampling points in June 2020

\begin{tabular}{ccccccc}
\hline \multirow{2}{*}{ Parameters } & $\begin{array}{c}\mathrm{Unit} \\
\mathrm{mg} / \mathrm{l}\end{array}$ & $\begin{array}{c}\mathrm{UA} \\
30 / 2014\end{array}$ & $\mathrm{M}_{1}$ & $\mathrm{M}_{2}$ & \multirow{2}{*}{$\mathrm{M}_{3}$} & \multirow{2}{*}{$\mathrm{M}_{4}$} \\
\hline $\mathrm{As}$ & $\mathrm{mg} / \mathrm{l}$ & 0.1 & 0.031 & $<0.002$ & $<0.002$ & $<0.002$ \\
$\mathrm{Cd}$ & $\mathrm{mg} / \mathrm{l}$ & 0.02 & $<0.0001$ & $<0.0001$ & $<0.0001$ & $<0.0001$ \\
$\mathrm{Cu}$ & $\mathrm{mg} / \mathrm{l}$ & 0.5 & $<0.0004$ & $<0.0004$ & $<0.0004$ & $<0.0004$ \\
$\mathrm{Fe}$ & $\mathrm{mg} / \mathrm{l}$ & 2 & 0.393 & 0.272 & 0.437 & 0.285 \\
$\mathrm{Mn}$ & $\mathrm{mg} / \mathrm{l}$ & 2 & 0.790 & 0.540 & 4.090 & 0.638 \\
$\mathrm{Ni}$ & $\mathrm{mg} / \mathrm{l}$ & 0.5 & $<0.0005$ & $<0.0005$ & 0.008 & $<0.0005$ \\
$\mathrm{~Pb}$ & $\mathrm{mg} / \mathrm{l}$ & 0.5 & 0.018 & 0.025 & 0.022 & 0.020 \\
$\mathrm{Sb}$ & $\mathrm{mg} / \mathrm{l}$ & 0.75 & $<0.002$ & 0.001 & 0.013 & $<0.002$ \\
$\mathrm{Zn}$ & $\mathrm{mg} / \mathrm{l}$ & 1 & 0.890 & 1.610 & 3.860 & 0.910 \\
$\mathrm{pH}$ & - & $6.5-9.0$ & 7.890 & 8.189 & 7.125 & 7.447 \\
\hline
\end{tabular}

The table data show the heavy metal concentration according to sampling points:

$\mathrm{M}_{1}$ - shows waters coming out of the Trepça Mine;

$\mathrm{M}_{2}$ - shows the Trepça River waters;

$\mathrm{M}_{3}$ - shows the flotation discharge waters;

$\mathrm{M}_{4}$ - shows the Kelmend landfill waters.

The water samples were taken in January and June 2020, Tables 1 and 2.

The results obtained from the analyses conducted in January give the following situation: in sampling points $\mathrm{M}_{1}$ and $\mathrm{M}_{4}$ no referring values pursuant to UA 30/2014 of any of the nine heavy metals analyzed in this study have been exceeded.

In sampling point $\mathrm{M}_{2}$ we encountered exceeded $\mathrm{Zn}$ referral values at a concentration of $1.11 \mathrm{mg} / \mathrm{l}$.

In sampling point $\mathrm{M}_{3}$ the referring values of $\mathrm{Mn}$ were exceeded at a concentration of $3.590 \mathrm{mg} / \mathrm{l}$ and $\mathrm{Zn}$ at $3.330 \mathrm{mg} / \mathrm{l}$.

The exceeding of referring values for $\mathrm{Mn}$ and $\mathrm{Zn}$ are shown as diagrams in Figure 7 (straight line).

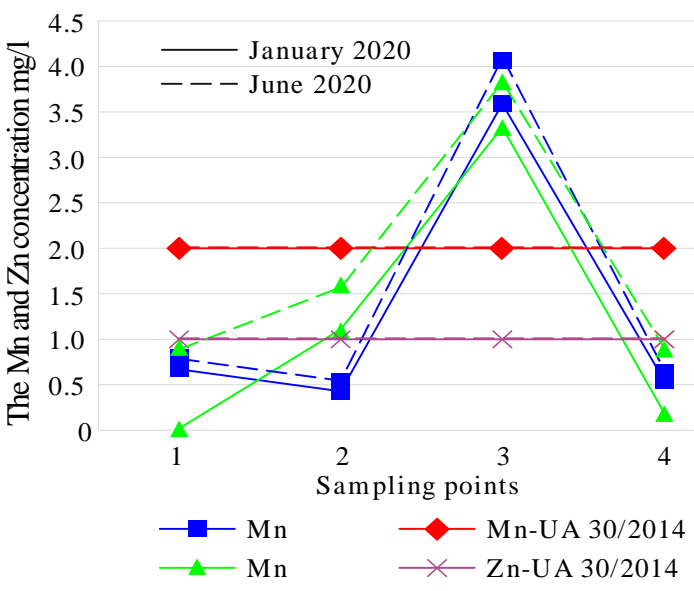

Figure 7. The Mn and $\mathrm{Zn}$ concentration according to sampling points - January 2020

To find out the concentration of heavy metals in our sampling points, not only during winter, we though appropriate to take other samples during summer (in June) as well, in order to have a realistic assessment of the situation.

The results obtained in June 2020 are shown in Table 2.

Table 2 shows no exceeding of heavy metals referring values in sampling points $\mathbf{M}_{1}$ and $\mathbf{M}_{4}$, whereas, in sampling point $\mathrm{M}_{2}$ (Trepça River waters), $\mathrm{Zn}$ results with an excess of $1.610 \mathrm{mg} / \mathrm{l}$ and in sampling point $\mathrm{M}_{3}$ (flotation discharge waters), $\mathrm{Zn}$ results with an excess of $3.860 \mathrm{mg} / \mathrm{l}$ and $\mathrm{Mn}$ with $4.090 \mathrm{mg} / \mathrm{l}$. Figure 7 (dotted lines) shows the $\mathrm{Mn}$ and $\mathrm{Zn}$ concentration that is not compliant with the referring values of UA 30/2014.

The $\mathrm{Zn}$ presence in Trepça River $\left(\mathrm{M}_{2}\right)$ in excess of referring values, happens because this river during its flow continuously carries deposits of mineralized drops from the rocks.

Due to the outdated technology in the ore enrichment plant and because all metals are not properly ennobled during the flotation process, in the flotation discharged water sample $\left(\mathrm{M}_{3}\right)$, we encountered high $\mathrm{Zn}$ and $\mathrm{Mn}$ concentration in both seasons, but particularly in June.

The increase of the $\mathrm{Zn}$ concentration level in sampling point $\mathrm{M}_{2}$ occurs as a result of the contact with the mineralized rock layers, whereas, the $\mathrm{Zn}$ and $\mathrm{Mn}$ concentration increase in sampling point $\mathrm{M}_{3}$ occurs as a consequence of the discharging of other waters from the flotation process. These mixed discharges are then discharged in Trepça River, thus, polluting this river. The lack of flora and fauna along the entire flow of Trepça River is a direct result of this.

\section{Conclusions}

During our research work we have managed to obtain water samples in four representative sampling points. In order to obtain a realistic situation of the waters, we have tried to present the realistic situation of the heavy metals concentration in the natural waters of Trepça Rivers, the mine waters discharged in this river, the discharged flotation waters and industrial waste waters in Kelmend landfill.

Samples were taken in January and June with the aim of accurate registration of heavy metals concentration during two opposite seasons in 2020.

Table results show that in sampling point $\mathrm{M}_{2}$, the $\mathrm{Zn}$ concentration exceeded the referring values at $1,11 \mathrm{mg} / \mathrm{l}$ in January and at $1.610 \mathrm{mg} / \mathrm{l}$ in June. 
In sampling point $\mathrm{M}_{3}$, the $\mathrm{Zn}$ concentration results at $3.330 \mathrm{mg} / \mathrm{l}$ in January, and at $3.860 \mathrm{mg} / \mathrm{l}$ in June.

At the same sampling point $\left(\mathrm{M}_{3}\right)$, the $\mathrm{Mn}$ concentration results at $3.590 \mathrm{mg} / \mathrm{l}$ in January, and at $4.090 \mathrm{mg} / \mathrm{l}$ in June.

The higher level of $\mathrm{Zn}$ and $\mathrm{Mn}$ concentration in June, compared to January, occurs as a result of significant atmospheric differences during these two seasons.

Replacing the outdated with modern technology, both in the mine and in the flotation, would have a positive impact not only in preventing the existing metal losses, but at the same time in reducing the pollution with heavy metals of natural waters and discharges from the mine and flotation. The use of advanced technology would also have a significant impact in preserving the environment around the Trepça Mine.

\section{Acknowledgements}

We thank the administrative personnel of Trepça Combine for their understanding, assistance, and support in the successful completion of this study. They have provided access for taking samples in the mine and the flotation, in the Combine statistics and physical access in the mine, galleries, flotation and the surrounding environment.

We also thank the technical staff of Agrovet Lab, who worked with utmost care and dedication in analyzing the samples sent by me.

Special thanks go to your editorial office staff for providing this cooperation opportunity to publish this paper.

\section{References}

[1] Kadriu, S., Malollari, I., Pula-Beqiri, L., Aliu, M., Sadiku, M., Baruti, B., \& Kelmendi, M. (2017). Presence of heavy metals in water and sediment of rivers Trepça and Sitnica. Journal of Environmental Protection and Ecology, 18(1), 10-21.

[2] NIikshiq-Kadriu, S. (2012). Impact of metallurgical-chemical dumps in Kelmend and Shupkove in contamination of rivers Ibar and Sitnica

\section{Флотація та дослідження концентрації важких металів у стічних водах шахти "Трепча", Косово}

\section{С. Кадріу, М. Садіку, М. Келменді, Е. Садріу}

Мета. Оцінка концентрації важких металів у промислових стічних водах шахти “Трепча”, вивчення процесу флотації та аналіз їх ролі у забрудненні міського довкілля.

Методика. В ході дослідження були обрані локації для забору проб. Спосіб забору, обсяг зразків, спосіб перевезення і максимальний час витримки зразка до хімічного аналізу відповідали стандарту ISO 5667:1.3. Перед визначенням деяких параметрів зразки зберігалися згідно з процедурою зберігання, запропонованою Американською Асоціацією Охорони Громадського Здоров'я, а для мінералізації важких металів із зразків забруднених стічних вод застосовувався метод ЕРА-3015А. Для визначення концентрації важких металів була використана методика ICP - OES (метод індуктивно зв'язаної плазми - емісійна оптична спектрометрія).

Результати. В результаті вивчення роботи шахти “Трепча" був зроблений висновок про те, що головна причина забруднення навколишнього середовища пов'язана із функціонуванням шахти та флотацією. Аналіз зразків стічних вод шахти і флотації дозволяє уявити реальну концентрацію важких металів у навколишньому середовищі. Виявлено більш високий рівень вмісту Zn i Mn y червні в порівнянні з січнем, що пояснюється значними атмосферними відмінностями протягом цих двох сезонів.

Наукова новизна. Визначено показники концентрації важких металів у стічних водах та їх зв'язок з погіршенням якості навколишнього середовища із використанням високотехнологічного лабораторного обладнання, що забезпечило максимальну точність отриманих результатів.

Практична значимість. Рекомендована заміна застарілих технологій на сучасні, як на руднику, так і в процесі флотації, що матиме позитивний вплив не лише на запобігання існуючих втрат металів, але в той же час і на зниження забруднення важкими металами природних вод і скидів.

Ключові слова: шахта, флотачія, стічні води шахти, промислові стічні води, важкі метали, забруднення

\section{Флотация и исследование концентрации тяжелых металлов в сточных водах шахты "Трепча", Косово}

\section{С. Кадриу, М. Садику, М. Келменди, Э. Садриу}

Цель. Оценка концентрации тяжелых металлов в промышленных сточных водах шахты “Трепча”, изучение процесса флотации и анализ их роли в загрязнении городской окружающей среды. with heavy metals and their determination with spectrometric methods. Doctor Thesis. Pristina, Kosovo: University of Prishtina.

pollution. New York, United States: Wiley.
[4] Bogdanović, G., Antonijević, M., Milanović, Z., Šerbula, S., \& Soko Banja, Srbija.

B] Bode, A., Zoga, P., Xhulaj, D., \& Xhulaj, S. (2010). Mining residues around lake Ohrid. Journal of Mining and Metallurgy, 46A(1), 23-31. Upravljanje otpadom iz rudarstva - nastanak i mogučnost prerade. Reciklaža i Održivi Razvoj, 4(1), 37-43.

Kadriu, S., Hoxha, B., Pula-Beqiri, L., Zeqiri, L., \& Kelmendi, M. national Environmental Application \& Science, 6(2), 270-278. sediment of river Ibër from landfill in Kelmend, Kosovo. Mining

Zeqiri, R., Zeqiri, I., Nikshiq-Kadriu, S., \& Aliu, M. (2015). The ternational Journal of Engineering Research, 4(3), 99-101.

Chys, ., Trus, I., Gomelya, M., Trembus, I., Pasalskiy, B., sorbents based on walnut shells in the processes of wastewater treatment from heavy metal ion. Journal of Ecological Engineering, 21(4), 128-133. https://doi.org/10.12911/22998993/119809

the design of sampling programmes and sampling techniques.
[12] [12] ISO 5667-3. (2012). Eater quality - Sampling - Part 3: Preservation and handling of ëater samples.

13] [13] APHA, AWWA, WEF. (2005). Standard methods for the exami-
nation of ëater and ëasteëater. New York, United States: American Public Health Association.

samples and extracts. Pittsburgh, United States: Duquesne University.

Udhëzimi Administrativë e MMPH-Nr 30/2014 të Kosovës, për kushtet, ndotura në rrjetin e kanalizimit publik dhe në trupin ujor. (2020). Retrieved from https://mmph.rks-gov.net/ II Simpozijo "Rnaliza stanja rudničkih voda Rudnika bakra Bor. In Landfill located in the village Kelmend of Mitrovica. Journal of Interhttps://doi.org/10.17950/ijer/v4s3/302 
Методика. В ходе исследования были выбраны локации для забора проб. Способ забора, объем образцов, способ перевозки и максимальное время выдержки образца до химического анализа соответствовали стандарту ISO 5667:1.3. Перед определением некоторых параметров образцы сохранялись согласно процедуре хранения, предписанной Американской Ассоциацией Охраны Общественного Здоровья, а для минерализации тяжелых металлов из образцов загрязненных сточных вод применялся метод EPA-3015А. Для определения концентрации тяжелых металлов была использована методика ICP - OES (метод индуктивно связанной плазмы - эмиссионная оптическая спектрометрия).

Результаты. В результате изучения работы шахты “Трепча" был сделан вывод о том, что главная причина загрязнения окружающей среды связана с функционированием шахты и флотацией. Анализ образцов сточных вод шахты и флотации позволяет представить реальную концентрацию тяжелых металлов в окружающей среде. Выявлен более высокий уровень содержания $\mathrm{Zn}$ и $\mathrm{Mn}$ в июне по сравнению с январем, что объясняется значительными атмосферными различиями в течение этих двух сезонов.

Научная новизна. Определены показатели концентрации тяжелых металлов в сточных водах и их связь с ухудшением качества окружающей среды с использованием высокотехнологичного лабораторного оборудования, что обеспечило максимальную точность полученных результатов.

Практическая значимость. Рекомендована замена устаревших технологий на современные, как в руднике, так и во флотации, что окажет положительное влияние не только на предотвращение существующих потерь металлов, но в то же время и на снижение загрязнения тяжелыми металлами природных вод и сбросов.

Ключевые слова: шахта, флотация, сточные воды шахты, промышленные сточные воды, тяжелые металлы, загрязнение

\section{Article info}

Received: 30 June 2020

Accepted: 6 November 2020

Available online: 7 December 2020 